\title{
MICROSCOPIC INVESTIGATION OF DEFECTS IN THERMALLY COMPRESSED POPLAR WOOD PANELS
}

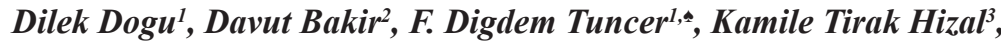 \\ Oner Unsal', Zeki Candan ${ }^{1}$
}

\begin{abstract}
The combined effects of temperature and compression on the microstructure of solid-wood panels produced by Aspen (Populus tremula) wood were evaluated. Thermal compression was applied on aspen wood to increase the density for improving its physical and mechanical properties. The solid wood panels with dimensions of $100 \mathrm{~mm}$ by $500 \mathrm{~mm}$ by $25 \mathrm{~mm}$ were hot-pressed by using a laboratory hot press at a temperature of either $150^{\circ} \mathrm{C}$ or $170^{\circ} \mathrm{C}$ and pressure of either $1 \mathrm{MPa}$ or $2 \mathrm{MPa}$, respectively, for $45 \mathrm{~min}$. Changes in the microstructure were detected by using a light microscope. The microscopic investigations revealed that the wood exhibited much defects in the process conditions of $170{ }^{\circ} \mathrm{C} / 2$ $\mathrm{MPa}$, and the distribution of defects were not uniform in the growth rings of the wood specimens in the two treatment groups. All defects in cell structure were quite distinct in the beginning and the last parts of the growth rings and the largest damages occurred in the fibers and vessels for the two process conditions. The results indicate that growth ring structure, vessel porosity, and cell wall thickness have a strong effect on wood behavior in various process conditions.
\end{abstract}

Keywords: Cellular failure, poplar wood, thermally compressed wood, wood densification, wood microstructure.

\section{INTRODUCTION}

In comparison to many other materials, wood is unique. It has been used throughout the history mostly because of its low cost, renewability, strength properties, and low processing energy requirements. Recently, there has been an increasing demand for industrial wood due to population and economic growth in the world. It is thought that timber production may not be able to meet the needs of forest products industry in the future. To overcome this phenomenon, the plantation forests and the fast growing tree species have received great attention during the last years (Hill 2006). However, wood formation with low density restricts the industrial usage of timber from fast-grown tree species. As known, most of the mechanical and physical properties of wood are clearly correlated with its density (Blomberg 2006).

Wood density can be increased by using some densification techniques (Blomberg 2006). Thermal compression of wood has been in use since World War II (Seborg et al. 1945), and compressed wood products using with low density wood species have been also produced in 1980s especially for utilization of some fast growing tree species (Norimoto 1993, Norimoto 1994, Wang et al. 2000).

\footnotetext{
${ }^{1}$ Department of Forest Industrial Engineering, Faculty of Forestry, Istanbul University, Istanbul, Turkey.

${ }^{2}$ Department of Forest Industrial Engineering, Faculty of Forestry, Artvin Coruh University, Artvin, Turkey.

${ }^{3}$ Department of Forest Industrial Engineering, Faculty of Forestry, Duzce University, Duzce, Turkey.

•Corresponding author: digdem.kangaloglu@istanbul.edu.tr

Received: 26.06.2015 Accepted: 19.02.2016
} 
Thermal compression is a wood modification method that combines thermal and mechanical processes and results in densification of wood. The main purpose of combining compression and heat on wood is to improve physical and mechanical properties as well as overcome weakness regarding low wood density and low surface hardness of fast growing trees (Gong and Lamason 2007, Tu et al. 2014, Guo et al. 2015). On the other hand, deformation by compression produced during densification process is not stable and the wood reverts totally or partially to its original shape after re-moistening and heating (Blomberg et al. 2006, Guo et al. 2015).

Improvements in the quality of timber are considerably related to changes in the chemical components in cell wall structures during thermal treatments, especially the degradation of amorphous carbohydrates (Fengel and Wegener 1984, Tjeerdsma et al. 1998, Boonstra and Tjeerdsma 2006, Boonstra et al. 2007, Kamdem et al. 2002, Awoyemi and Jones 2011). Although desired changes in wood properties start to appear at about $150{ }^{\circ} \mathrm{C}$ (ThermoWood Handbook 2003), damages in wood microstructure become frequent at $150{ }^{\circ} \mathrm{C}$ and above (Fengel and Wegener 1984, Terziev et al. 2002, Boonstra et al. 2006a, Boonstra et al. 2006b, Awoyemi and Jones 2011, Altgen et al. 2015, Batista et al. 2015).

Even though changes in the anatomical structure of wood at various temperatures have been studied in detail, there is limited information about the microstructure of different wood species subjected to thermal compressing process.

Dogu et al. (2010) found that the distribution of deformation was not uniform in the growth rings and the highest deformation occurred in earlywood regions for all process conditions (temperature of either $120^{\circ} \mathrm{C}$ or $150^{\circ} \mathrm{C}$ and pressure of either 5 or $7 \mathrm{MPa}$ for $1 \mathrm{~h}$ ) on thermally compressed Scots pine wood. Buckling and ruptures were detected particularly cell walls of the earlywood tracheids, also separations between compound middle lamella were detected. Cell-wall thickness was evaluated as an important factor in wood behavior during thermal compressing processes. The study showed that a homogenous structure of growth rings with the uniform earlywood and latewood widths plays a major role in prevention of cell collapse.

Tirak Hizal et al. (2012) noticed that the largest damages were particularly in the axial parenchyma and vessel cell walls of thermally compressed river red gum wood. Cell collapse occurred in almost all axial parenchyma for all process conditions (temperature of either $150^{\circ} \mathrm{C}$ or $180^{\circ} \mathrm{C}$ and pressure of 2 $\mathrm{MPa}$ for $45 \mathrm{~min}$.) and severe damages were observed in the cell walls of vessels and ray parenchyma at the highest temperature.

Examination of compressive deformation of hybrid poplar (Populus deltoids $\mathrm{x}$ Populus trichocarpa) wood in saturated steam, transient condition and in superheated steam at $150^{\circ} \mathrm{C}, 160^{\circ} \mathrm{C}$, and $170^{\circ} \mathrm{C}$ revealed that the wood was densified without cell wall fracture in all treatments. It was assumed that the wood samples contained tension wood in high degree, and therefore the storage modulus and softening temperature were lower than normal wood (Kutnar et al. 2012).

Microscopic observation revealed that the deformations present in thermo-mechanically densified Populus tomentosa wood arose from the viscous buckling of cell walls without fracture. Collapses in the vessels and flatting in the direction of the compression were determined (Tu et al. 2014).

Dogu et al. (2015) examined the microstructure of thermally compressed paulownia wood at a temperature of either $150^{\circ} \mathrm{C}$ or $170^{\circ} \mathrm{C}$ and pressure of $2 \mathrm{MPa}$ for $45 \mathrm{~min}$. and reported that deformations in the cell walls were promoted by increased temperature. Microscopic investigation showed that deformations were especially on axial parenchyma, fiber and vessel cell walls.

Physical and mechanical properties of the aspen wood were examined by Candan et al. (2013b). It was stated that the moisture content (MC) of the aspen wood panels decreased with increasing press temperature or press pressure. The average $\mathrm{MC}$ value of the unmodified aspen wood panels was around $15 \%$ while the $\mathrm{MC}$ value of the panels modified with $170^{\circ} \mathrm{C}$ was around $10 \%$. The average density values of the aspen wood panels increased by press pressure. As for mechanical performance, janka hardness values were improved by the thermal compression technique. The maximum increase in the 
janka hardness property was around $32 \%$.

Depending on process conditions, thermal compression process could also affect physical (Wang et al. 2000, Epmeier et al. 2003, Wang and Cooper 2005b, Gong and Lamason 2007, Johansson 2008, Candan et al. 2010, Candan et al. 2013b), mechanical (Wang and Cooper 2005a, Unsal and Candan 2007, Unsal and Candan 2008, Abraham et al. 2010, Unsal et al. 2011a, Unsal et al. 2011b, Kutnar et al. 2012, Candan et al. 2013a) and durability (Kamdem et al. 2002, Edlund and Jermer 2004, Hakkou et al. 2006, Unsal et al. 2009, Boonstra et al. 2007) properties of wood.

Wood properties in nature vary among tree species, between trees of the same species, between pieces from the same tree as well. The behavior of wood in different process conditions will be most likely different. Therefore, it is important to know the effects of modification methods in anatomical structure to evaluate the success of the methods. Aspen (Populus tremula) is one of the fast growing tree species in Turkey. Wide availability and the low cost are some of the advantages of that wood species. However, it has also some undesired properties such as low surface hardness, low density, low dimensional stability and some drying problems (Candan et al. 2013b). In the recent study, thermal compression was applied on aspen wood to improve those undesired properties (Candan et al. 2013b). The aim of this study was to evaluate the effects of varying temperatures and press pressures on the microstructure of solid-wood panels produced by using aspen wood.

\section{MATERIALS AND METHODS}

This study was performed on wood samples, which exposed to two different thermal compression process, were taken from the materials examined by Candan et al. (2013b). Aspen solid wood panels having no defects with dimensions of $100 \mathrm{~mm}$ by $500 \mathrm{~mm}$ by $25 \mathrm{~mm}$ were hot pressed using a laboratory hot press at a temperature of either $150^{\circ} \mathrm{C}$ or $170{ }^{\circ} \mathrm{C}$ and pressure of either $1 \mathrm{MPa}$ or $2 \mathrm{MPa}$, respectively, for $45 \mathrm{~min}$. A total of four panels (two compressed panels from each treatment group) were tested. The panels were pre-dried to a moisture content of $15 \%$ before hot pressing (Candan et al. 2013b).

Light Microscopy (LM) was employed to reveal deformations in the anatomical structure of the panels subjected to varying thermal compression conditions. Small wood samples were obtained from the outer region of cross sections of the solid wood panels in order to eliminate possible effects of juvenile wood. The samples with dimensions of $10 \mathrm{~mm}(\mathrm{R})$ x $10 \mathrm{~mm}(\mathrm{~T})$ × $20 \mathrm{~mm}(\mathrm{~L})$ were cut for the LM evaluations. These samples were kept under vacuum in the presence of alcohol : glycerin : water $(1: 1: 1)$ at room temperature in order to become softened and were then cut into thin sections (about 20 $\mu \mathrm{m}-30 \mu \mathrm{m}$ ) by using a Leica SM 2010R sliding microtome. The microtome knife was often changed to minimize surface roughness and any possible artificial damage on the surfaces of the samples. The sections were then stained with safranin and fast green according to standard techniques to supply good contrast between cell walls (Wilcox 1964, Ruzin 1999). A microscopic slide of aspen wood from the Xylarium of Faculty of Forestry, Istanbul University (ISTUFw) served as control. The microscopic sections were already stained by safranin.

The microscopic sections were observed under an Olympus BX51 Light Microscope. Images were taken by using analySIS FIVE Software and a DP71 Digital Camera installed and adapted on the microscope.

All microscopic studies were only realized visually on the microscopic sections. 


\section{RESULTS AND DISCUSSION}

Changes in anatomical structure were investigated to understand the effects of temperature and compression and the results were evaluated separately for each treatment. In this study, repeated micro-damages in the thermally compressed wood structure were taken into account to avoid wrong interpretation. Images of untreated wood samples are shown in Figure 1 and Figure 2 for comparison. Aspen wood is diffuse- to semi-ring-porous, growth ring boundaries are distinct. Vessels are partly solitary, partly in radial multiples of 2 to 4 . Axial parenchyma are apotracheal diffuse and in marginal bands. Rays are exclusively uniseriate and homogeneous with procumbent cells. Inter-vessel pits are alternate. Perforation plate is simple. Vessel-ray pits are with much reduced borders to apparently simple: pits rounded or angular, or restricted to marginal rows are extremely large and simple. Fibres are with simple to minutely bordered pits (IAWA Committee 1989, Schoch et al. 2015).

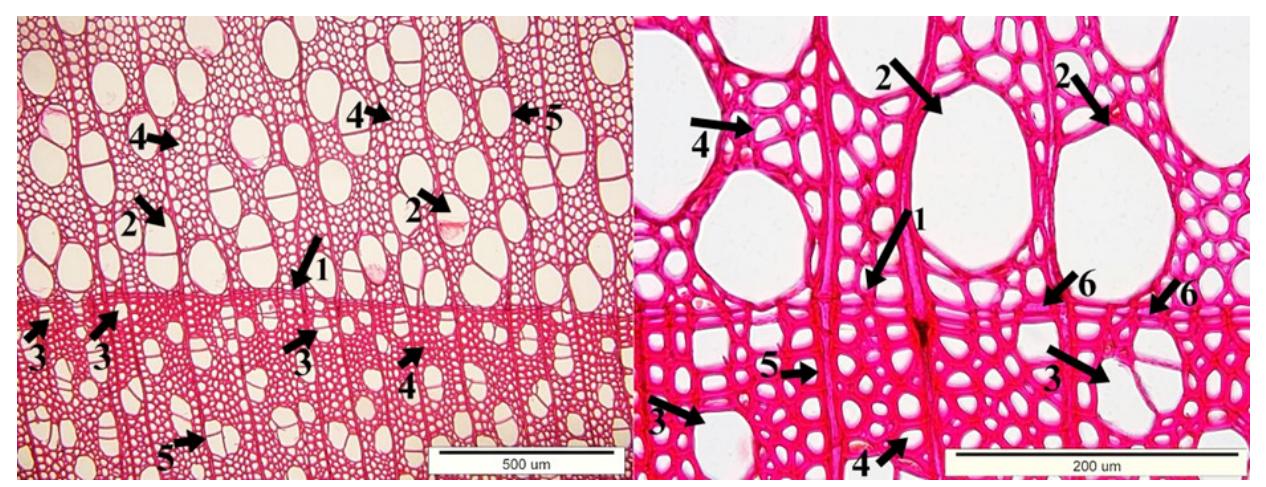

Figure 1. Light micrographs of untreated wood in different magnifications.

Arrows: 1.Growth ring boundary, 2. Earlywood vessels, 3. Latewood vessels, 4. Fibers, 5. Rays, 6. Axial parenchyma cells in marginal band (cross sections).

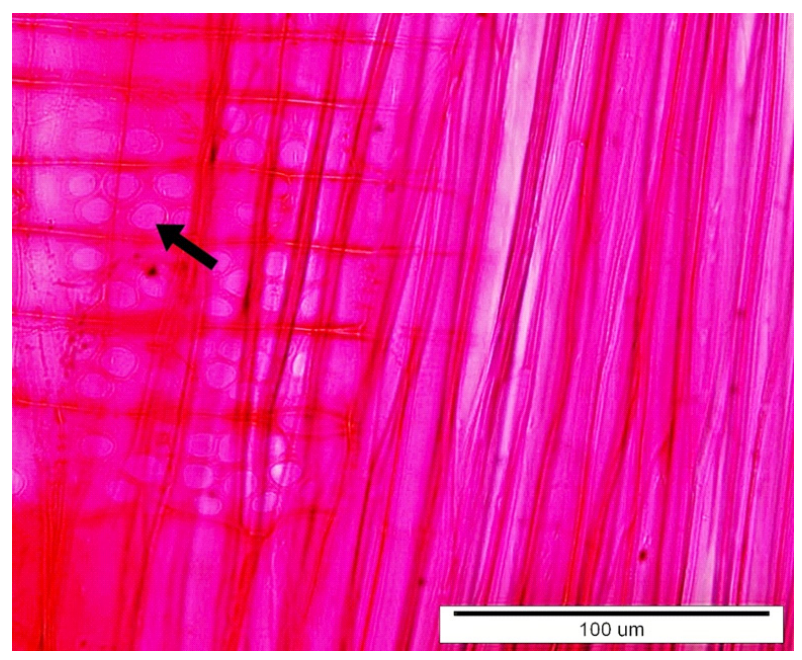

Figure 2. Light micrographs of untreated wood (radial section) Vessel-ray pits (arrow).

\section{Process Condition of $150{ }^{\circ} \mathrm{C} / 1 \mathrm{MPa}$}

Minimum structural damage and no visible distortion in the plane of growth rings were observed in cross sections at $150{ }^{\circ} \mathrm{C} / 1 \mathrm{MPa}$ (Figure 3). The vessels and the fiber cells were also in their natural shapes considerably (Figure 3 ). Minute cracks and low degree damage were observed particularly in the cell wall of the fibers and vessels located in the beginning and the last part of the growth rings (Figure 
4 and Figure 5). Slight separations between compound middle lamella in fiber cells were noticed. Both damaged and undamaged bordered pits were also found in the cell walls of vessels arranged in the radial rows of 2 to 4 multiples. On the radial section, slight separations between compound middle lamella in ray parenchyma cells were noticed and no visible damages were seen on cross-field pits (Figure 6).

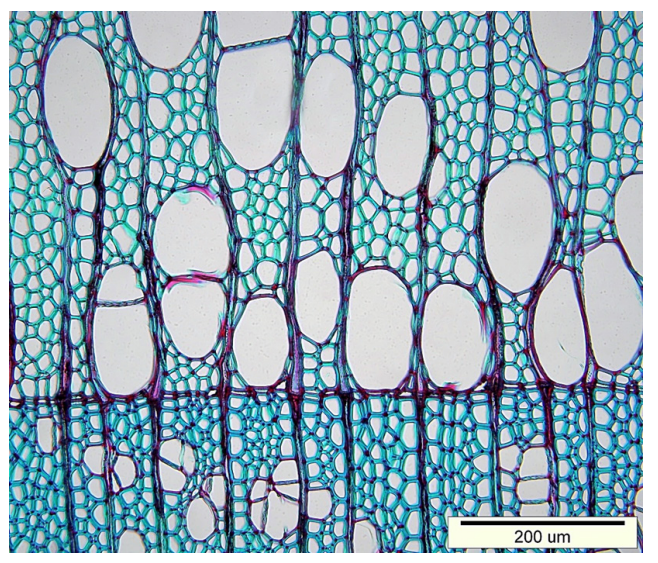

Figure 3. No visible distortion in the plane of growth rings at $150{ }^{\circ} \mathrm{C} / 1 \mathrm{MPa}$ (cross sections).

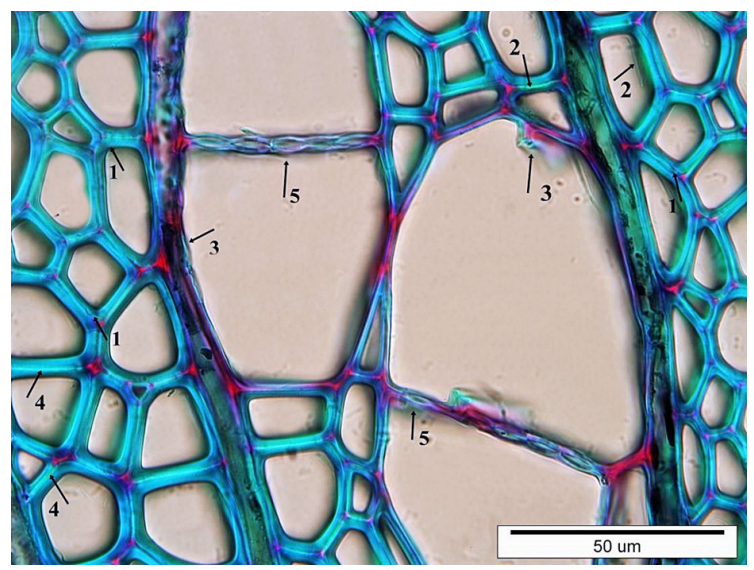

Figure 4. Minute cracks in the fiber cell walls (arrow 1) and low degree cell wall damages in the fibers (arrow 2) and the vessels (arrow 3 ) in the beginning part of the growth ring, slight separations between compound middle lamella in fiber cells (arrow 4) damaged bordered pits in the vessel cell walls (arrow 5) at $150^{\circ} \mathrm{C} / 1 \mathrm{MPa}$ (cross section). 


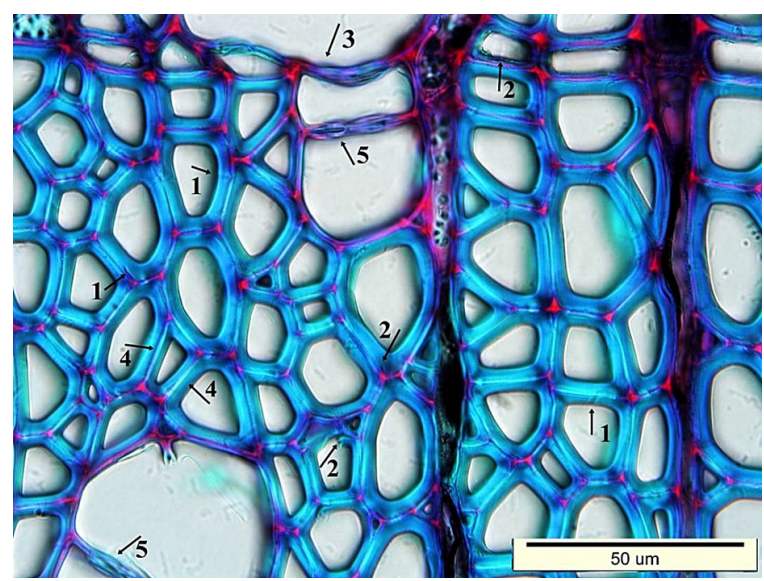

Figure 5. Minute cracks in the fiber cell walls (arrow 1) and low degree cell wall damages in the fibers (arrow 2) and the vessels (arrow 3 ) in the last part of the growth ring, slight separations between compound middle lamella in fiber cells (arrow 4) damaged bordered pits in the vessel cell walls (arrow 5) at $150^{\circ} \mathrm{C} / 1 \mathrm{MPa}$ (cross section).

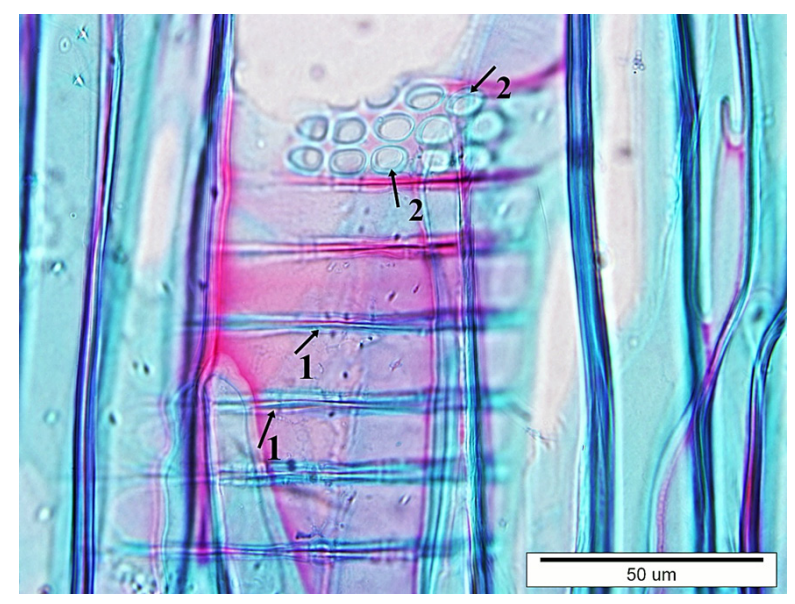

Figure 6. Slight separations between compound middle lamella in ray parenchyma cells (arrow 1), no visible damages on cross-field pits (arrow 2 ) at $150{ }^{\circ} \mathrm{C} / 1 \mathrm{MPa}$ (radial section).

\section{Process Condition of $170^{\circ} \mathrm{C} / 2 \mathrm{MPa}$}

Depending on the process condition, much more damages were observed in the wood microstructure at $170{ }^{\circ} \mathrm{C} / 2 \mathrm{MPa}$. Buckling on the radial cell walls of the vessels were found clearly in the initial part of the growth rings. These structural alterations on vessels resulted in a slight wavy pattern in the relevant regions and in the rays (Figure 7) On the other hand, no collapse was observed in the cells. It was thought that the buckling in the radial cell walls of vessels was an indication that abrupt fractures would occur. Ruptures were also seen in the vessel cell walls. Distinct cracks and severe degradation were observed in the fiber cell walls located in the beginning and the last part of the growth rings. It was also seen distinct separations between compound middle lamella in the fiber cells (Figure 8 and Figure 9). A great number of ruptured bordered pits were detected in the tangential cell walls of vessels arranged in the radial rows of 2 to 4 multiples. On the radial section, slight separations between compound middle lamella in horizontal ray parenchyma cells were noticed and the less damage was seen on cross-field pits. Besides, the low degree damage in the horizontal cell walls of rays was also 
observed in radial section (Figure 10).

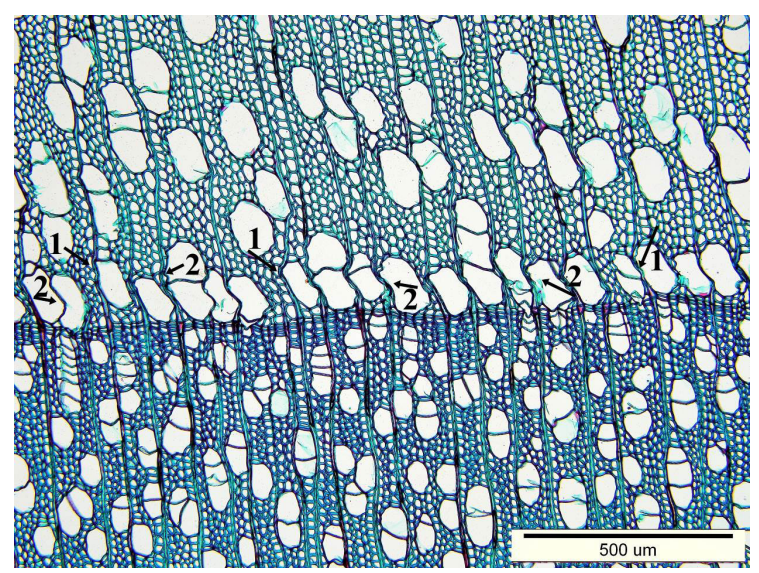

Figure 7. Slight wavy pattern at the initial part of earlywood region and in the rays (arrow 1) caused by buckling on the radial cell walls of the vessels (arrow 2) at $170{ }^{\circ} \mathrm{C} / 2 \mathrm{MPa}$ (cross section).

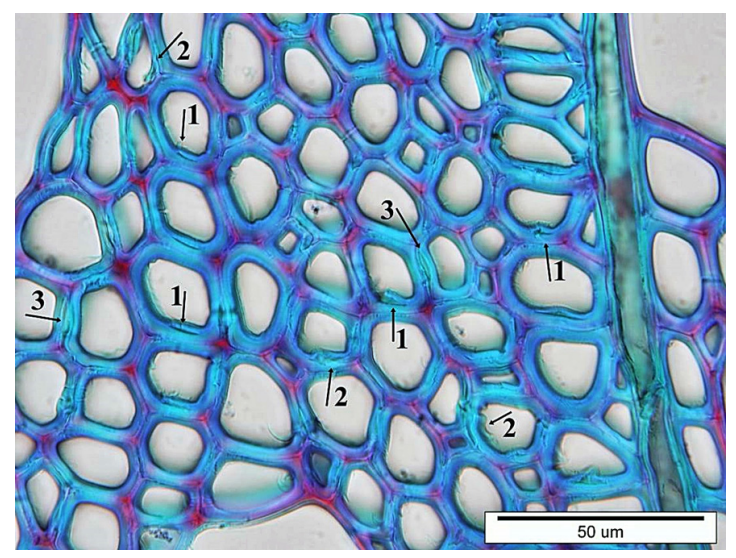

Figure 8. Distinct cracks (arrow 1) and severe damage (arrow 2) in the fiber cell walls, distinct separations between compound middle lamella in fiber cells (arrow 3 ) in the beginning part of growth ring at $170{ }^{\circ} \mathrm{C} / 2 \mathrm{MPa}$ (cross section).

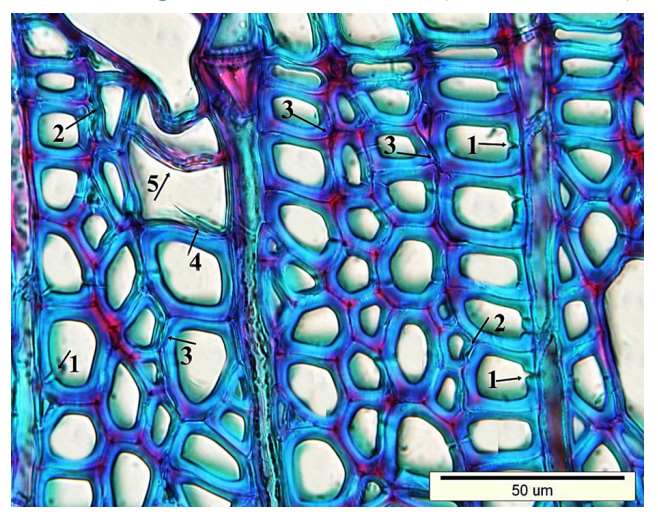

Figure 9. Distinct cracks (arrow 1) and severe degradations (arrow 2) in the fiber cell walls, distinct separations between compound middle lamella in fiber cells (arrow 3), ruptures in the vessel cell walls (arrow 4), damaged bordered pits in the vessel cell walls (arrow 5) in the last part of growth ring at $170{ }^{\circ} \mathrm{C} / 2 \mathrm{MPa}$ (cross section). 


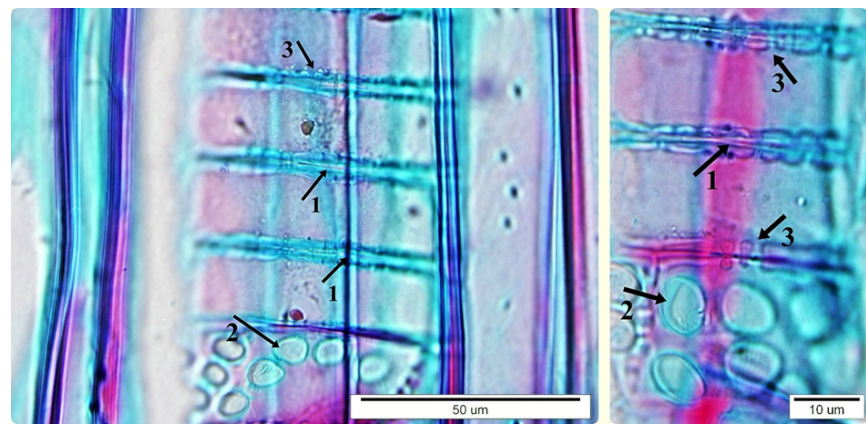

Figure 10. Slight separations between compound middle lamella in horizontal ray parenchyma cells (arrow 1), less damage on cross-field pits (arrow 2) and the low degree defects in the horizontal walls of ray parenchyma cells (arrow 3 ) at $170{ }^{\circ} \mathrm{C} / 2 \mathrm{MPa}$ (radial section).

This study showed that much more damages in thermally compressed samples at $170{ }^{\circ} \mathrm{C} / 2 \mathrm{MPa}$ were seen when compared to compressed samples at $150{ }^{\circ} \mathrm{C} / 1 \mathrm{MPa}$ and the distribution of defects was not uniform in the growth rings of two treatment groups. All deformation in cell structure was quite distinct at the beginning and the last part of the growth rings and the largest damage occurred in the fibers and vessels. The similar findings were obtained in densified white ash (Tabarsa and Chui 2001) and Populus ussuriensis (Ou et al. 2014) and paulownia (Dogu et al. 2015) woods. On the other hand, some authors reported that morphological changes between the earlywood and the latewood regions of Populus spp. were not different under densification process (Tabarsa and Chui 2001, Kutnar et al. 2009, Tu et al. 2014). The contradiction among the results of studies may be based on the process conditions, usage of different wood species and the wood properties such as different growth ring structure and different amount of latewood and earlywood. Tu et al. (2014) mentioned that a high densification ratio will lead to a higher rate of deformation in the wood cells, as well as uniform distribution throughout the growth ring in Populus tomentosa. Candan et al. (2013b) indicated that the percentage of maximum increase in density was $18 \%$, at $170{ }^{\circ} \mathrm{C} / 2 \mathrm{MPa}$. Kutnar and Šernek (2007) indicated that the increase in density was in the range of about $25 \%$ to about $500 \%$, though preferably in the range of about $100 \%$ to about $200 \%$ in the densified wood. In this context, even the maximum density did not reach to value of $25 \%$ in the current study. On the other hand, the vessel porosity of wood is diffuse- to semi-ring-porous in the study and the vessels in the earlywood are larger than those in the latewood of the previous and of the same growth ring. Cell wall thickness of fibers is also visually clear different in the same regions of the growth rings. Therefore, it was considered that distribution of stresses was not homogenous throughout the growth rings resulted in differentiation in the severity of micro-defects. 


\section{CONCLUSIONS}

Microscopic investigations on thermally compressed aspen wood revealed that the highest damages occurred in fibers and the vessels and changes in microstructure were not uniform in the growth rings for the two treatment groups.

The contradiction among the results of different studies performed on poplar wood indicated that growth ring structure and vessel porosity have a strong effect on wood behavior in various process conditions. In this context, further studies on the microstructure of wood subjected to different modification methods are needed.

\section{ACKNOWLEDGEMENTS}

This manuscript is an extension and continuation of the study presented at the ICWSE.

\section{REFERENCES}

Abraham, J.; Nemeth, R.; Molnar, S. 2010. Thermomechanical densification of Pannonia Poplar. Proc. of the final conference of COST Action E53: Quality control for wood \& wood products Edinburgh, Scotland, 282-292.

Altgen, M.; Adamopoulos, S.; Militz, H. 2015. Wood defects during industrial-scale production of thermally-modified Norway spruce and Scots pine. Wood Mater Sci Engin DOI: $10.1080 / 17480272.2014 .988750$.

Awoyemi, L.; Jones, I.P. 2011. Anatomical explanations for the changes in properties of western red cedar (Thuja plicata) wood during heat treatment. Wood Science and Technology 45: 261-267.

Batista, D.C.; Paes, J.B.; Bolzón De Muñiz, G.I.; Nisgoski, S.; Da Silva Oliveira, J.T. 2015. Microstructural aspects of thermally modified Eucalyptus grandis wood. Maderas. Ciencia y Tecnología 17: 525-532.

Blomberg, J. 2006. Mechanical and Physical Properties of Semi-Isostatically Densified Wood. Ph.D. Thesis, Luleå University of Technology, Luleå, Sweden.

Blomberg, J.; Persson, B.; Bexell, U. 2006. Effects of semi-isostatic densification on anatomy and cell-shape recovery on soaking. Holzforschung 60:322-331.

Boonstra, M.; Rijsdijk, J.F.; Sander, C.; Kegel, E.; Tjeerdsma, B.; Militz, H.; Van Acker, J.; Stevens, M. 2006a. Microstructural and physical aspects of heat treated wood. Part 1: Softwoods. Maderas. Ciencia y Tecnología 8: 193-208.

Boonstra, M.; Rijsdijk, J.F.; Sander, C.; Kegel, E.; Tjeerdsma; B.; Militz; H.; Van Acker, J.; Stevens, M. 2006b. Microstructural and physical aspects of heat treated wood. Part 2: Hardwoods. Maderas. Ciencia y Tecnología 8: 209-217.

Boonstra, M. J.; Van Acker, J.; Pizzi, A. 2007. Anatomical and molecular reasons for property changes of wood after full-scale industrial heat treatment. Paper of the 3rd European Conference on Wood Modification. Zürich. 343-358. 
Boonstra, M.J.; Tjeerdsma, B.F. 2006. Chemical analysis of heat-treated softwoods. Holz als Roh und Werkstoff 64: 204-211.

Candan, Z.; Hiziroglu, S.; Medonald, A.G. 2010. Surface quality of thermally compressed Douglas fir veneer. Materials and Design 31: 3574-3577.

Candan, Z.; Korkut, S.; Unsal, O. 2013a. Effect of thermal modification by hot pressing on performance properties of paulownia wood boards. Industrial Crops and Products 45: 461-464.

Candan, Z.; Korkut, S.; Unsal, O. 2013b. Thermally compressed Poplar wood (TCW): Physical and mechanical properties. Drvna Industrija 64: 107-211.

Dogu, D.; Tirak, K.; Candan, Z.; Unsal, O. 2010. Anatomical investigation of thermally compressed wood panels. BioResources 5: 2640-2663.

Dogu, D.; Tirak Hizal K.; Bakir D.; Tuncer F.D.; Candan Z.; Ünsal Ö. 2015. Anatomical Structures of Thermally Compressed Paulownia (Paulownia spp.) Wood. Proceedings of the 58th International Convention of Society of Wood Science and Technology, Wyoming, ABD, 7-12 June 2015, pp.304-304.

Edlund, M.L.; Jermer, J. 2004. Durability of heat-treated wood. COST action E22 Environmental Optimization of Wood Protection, Lisboa, - Portugal, $22^{\text {nd }}-23^{\text {rd }}$ March.

Epmeier, H.; Westin, M.; Rapp, A.O.; Nilsson, T. 2003. Comparison of Properties of Wood Modified by 8 Different Methods - Durability, Mechanical and Physical Properties. The First European Conference on Wood Modification, Ghent, Belgium.

Fengel, D.; Wegener, G. 1984. Wood: chemistry, ultrastructures, reactions. Walter de Gruyter and Co. Berlin.

Gong, M.; Lamason, C. 2007. Improvement of surface properties of low density wood: Mechanical modification with heat treatment. Research report, Project No: UNB57, Value to Wood No: UNB57 Natural Resources Canada.

Guo, J.; Song, K.; Salmen, L.; Yin, Y. 2015. Changes of wood cell walls in response to hygromechanical steam treatment. Carbohydrate Polymers 115: 207-214.

Hakkou, M.; Petrissans, M.; Gerardin, P.; Zoulalian, A. 2006. Investigations of the reasons for fungal durability of heat-treated beech wood. Polymer Degradation and Stability 91: 393-397.

Hill, C. 2006. Wood modification, chemical, thermal and other processes. Wiley, West Sussex, UK.

IAWA Committee. 1989. IAWA List of Microscopic Features For Hardwood Identification. IAWA Bulletin 10: 219-332.

Johansson, D. 2008. Heat Treatment of Solid Wood: Effects on Absorption, Strenght and Colour. Doctoral Thesis, Lulea University of Technology, Luleå, Sweden.

Kandem, D.P.; Pizzi, A.; Jermannaud, A. 2002. Durability of heat treated wood. Holz als Roh und Werkstoff 60: 1-6.

Kutnar, A.; Šernek, M. 2007. Densification of wood. Zbornik Gozdarstva in Lesarstva 82: 53-62. 
Kutnar, A.; Kamke, F.A.; Sernek, M. 2009. Density profile and morphology of viscoelastic thermal compressed wood. Wood Science and Technology 43: 57-68.

Kutnar, A.; Widmann, R.; Kamke, F.A. 2012. Density, mechanical properties, and morphology of densified wood in relation to compression temperature and steam environments. Proc. of $8^{\text {th }}$ European Conference on Wood Modification, Ljubljana, Slovenia,

167-174.

Norimoto, M. 1993. Large compressive deformation in wood. Mokuzai Gakkaishi 39: 867-874.

Norimoto, M. 1994. Heat treatment and steam treatment of wood. Wood Industry 49: 588- 592.

Ou, R.; Xie, Y.; Wang, Q.; Sui, S.; Wolcott, M.P. 2014. Thermoplastic deformation of poplar wood plasticized by ionic liquids measured by a nonisothermal compression technique. Holzforschung 68: 555-566.

Ruzin, S.E. 1999. Plant Microtechnique and Microscopy. Oxford University Press, New York.

Seborg, R.M.; Millet, M.A.; Stamm, A.J. 1945. Heat-stabilized compressed wood (Staypak). Mec Eng 67: 25-31.

Schoch, W.; Heller, I.; Schweingruber, F. H.; Kienast, F. 2015. Wood anatomy of central European Species. www.woodanatomy.ch.

Tabarsa, T.; Chui, Y.H. 2001. Characterizing microscopic behaviour of wood under transverse compression. Part II. Effect of species and loading direction. Wood and Fiber Science 33: 223-232.

Tirak Hizal, K.; Doğu, A.D.; Candan, Z.; Ünsal, Ö. 2012. Anatomical Investigation of Thermally Compressed Eucalyptus Wood Panels. $55^{\text {th }}$ International Convention of Society of Wood Science and Technology. China, 1-7.

Terziev, N.; Daniel, G. 2002. Industrial kiln drying and its effect on microstructure, impregnation and properties of Scots pine timber impregnated for above ground use. Part 2. Effect of drying on microstucture and some mechanical properties of Scots pine wood. Holzforschung 56: 434-439.

Thermowood Handbook, 2003. Finnish Thermowood Association c/o Wood Focus Oy, P.O. Bo284 (Snellmaninkatu 13), FIN-00171 Helsinki, Finland.

Tjeerdsma, B.F.; Boonstra, M.; Pizzi, A.; Tekely, P.; Militz, H. 1998. Characterisation of thermally modified wood: molecular reasons for wood performance improvement. Holz als Roh- und Werkstoff 56: 149-153.

Tu, D.; Su, X.; Zhang, T.; Fan, W.; Zhou, Q. 2014. Thermo-mechanical densification of Populus tomentosa var. tomentosa with low moisture content. BioResources 9: 3846-3856.

Unsal, O.; Candan, Z. 2007. Effects of press pressure and temperature on the moisture content, vertical density profile and janka hardness of pine wood panels. Proc. of $10^{\text {th }}$ International IUFRO Wood Drying Conference, Maine, USA.

Unsal, O.; Candan, Z. 2008. Moisture content, vertical density profile and Janka hardness of thermally compressed pine wood panels as a function of press pressure and temperature. Drying Technology 26: 1165-1169.

Unsal, O.; Kartal, S.N.; Candan, Z.; Arango, R.A.; Clausen, C.A.; Green, F. 2009. Decay and termite resistance, water absorption and swelling of thermally compressed wood panels. International Biodeterioration and Biodegradation 63: 548-552. 
Unsal, O.; Candan, Z.; Korkut, S. 2011a. Wettability and roughness characteristics of modified wood boards using a hot-press. Industrial Crops and Products 34: 1455-1457.

Unsal, O.; Candan, Z.; Buyuksari, U.; Korkut, S.; Chang, Y.S.; Yeo, H. 2011b. Effect of thermal compression treatment on the surface hardness, vertical density profile, thickness swelling of eucalyptus wood boards by hot pressing. Journal of Korean Wood Science and Technology 39: 148155.

Wang, J.M.; Zhao, G.J.; Lida, I. 2000. Effect of oxidation on heat fixation of compressed wood of China fir. Forestry Studies in China 2: 73-79.

Wang, J.; Cooper, P.A. 2005a. Vertical density profiles in thermally compressed balsam fir wood. Forest Products Journal 55: 65-68.

Wang, J.; Cooper, P.A. 2005b. Effect of grain orientation and surface wetting on vertical density profiles of thermally compressed fir and spruce. Holz als Roh und Werkstoff 63: 397-402.

Wilcox, W. W., 1964. Preparation of Decayed Wood For Microscopical Examination. U.S. Forest Service Research Note, FPL-056.Madison, Wisconsin. 